\title{
Delineation of a fault zone beneath a riverbed by an electrical resistivity survey using a floating streamer cable
}

\author{
Hyoung-Seok Kwon' Jung-Ho Kim ${ }^{2}$ Hee-Yoon Ahn ${ }^{3}$ Jin-Sung Yoon ${ }^{3}$ Ki-Seog Kim ${ }^{3}$ \\ Chi-Kwang Jung ${ }^{4}$ Seung-Bok Lee ${ }^{5}$ Toshihiro Uchida'
}

Key Words: streamer resistivity survey, fault zone, continuous resistivity profiling, water-covered area

\begin{abstract}
Recently, the imaging of geological structures beneath watercovered areas has been in great demand because of numerous tunnel and bridge construction projects on river or lake sites. An electrical resistivity survey can be effective in such a situation because it provides a subsurface image of faults or weak zones beneath the water layer. Even though conventional resistivity surveys in water-covered areas, in which electrodes are installed on the water bottom, do give high-resolution subsurface images, much time and effort is required to install electrodes. Therefore, an easier and more convenient method is sought to find the strike direction of the main zones of weakness, especially for reconnaissance surveys.
\end{abstract}

In this paper, we investigate the applicability of the streamer resistivity survey method, which uses electrodes in a streamer cable towed by ship or boat, for delineating a fault zone. We do this through numerical experiments with models of water-covered areas. We demonstrate that the fault zone can be imaged, not only by installing electrodes on the water bottom, but also by using floating electrodes, when the depth of water is less than twice the electrode spacing. In addition, we compare the signal-to-noise ratio and resolving power of four kinds of electrode arrays that can be adapted to the streamer resistivity method.

Following this numerical study, we carried out both conventional and streamer resistivity surveys for the planned tunnel construction site located at the Han River in Seoul, Korea. To obtain highresolution resistivity images we used the conventional method, and installed electrodes on the water bottom along the planned route of the tunnel beneath the river. Applying a two-dimensional inversion scheme to the measured data, we found three distinctive low-resistivity anomalies, which we interpreted as associated with fault zones. To determine the strike direction of these three fault zones, we used the quick and convenient streamer resistivity

' Geological Survey of Japan, AIST

1-1-1 Higashi, Tsukuba, 305-8567, Japan

Phone: 029-861-3611

Facsimile: 029-861-3618

Email: caf2-kwon@aist.go.jp

2 Korea Institute of Geoscience and Mineral Resources 30 Gajeong-dong, Yuseong-gu, Daejeon, 305-350, Korea

3 Heesong Geotek Co., Ltd.

90-9 Yangjae-dong, Seocho-gu, Seoul, 137-890, Korea

4 ESCO Engineers \& Consultant Co., Ltd.

869-9 Bangbae-dong, Seocho-gu, Seoul, 137-060, Korea

5 Samsung Engineering \& Construction

263 Seohyeon-dong, Bundang-gu, Seongnam, Gyeonggi-do, 463-721, Korea

Manuscript received August 9, 2004; accepted November 19, 2004. Part of this paper was presented at the 7th SEGJ International Symposium (2004). survey on additional grid-style survey lines. In this way, we could delineate the strike direction of faults beneath the riverbed very efficiently.

\section{INTRODUCTION}

Because waterways may develop by preferential erosion in shear zones or along other geological lineaments, weak zones such as faults might be expected beneath rivers or lakes. Thus, in planning construction of a bridge or tunnel passing through a river or lake, careful evaluation of geological conditions must be carried out. The strike direction of significant faulting is one of the crucial factors in the design of a tunnel. However, because the water layer overlies the rock mass, only drilling and in-situ borehole tests have been available in the past. Although test drilling is expensive, it still provides only discontinuous information. Recently, electrical resistivity surveys have been shown to have an important role in investigating water-covered areas, because they can produce continuous underground images efficiently (Chung et al., 2001, Kim et al., 2002a, Cho et al., 2004). Active faults are often imaged as low resistivity zones (e.g., Fujita and Ikuta, 2000; Unsworth and Bedrosian, 2004), so that such continuous imaging of resistivity structure can be a powerful tool for mapping weak zones. In addition, since a resistivity survey is sensitive to vertical structure, we can expect to readily delineate the location of vertical weak zones from these images.

There are two choices for electrode installation to obtain electrical resistivity data in water-covered areas. One is to emplace the electrodes on the water bottom, and the other is to use electrodes floating on the water surface. We refer to the former as the water-bottom-emplacement (WBE) method and the latter as the floating-electrode method in this paper (see Figure 15). Kim et al. (2002b) investigated the effect of a thick water layer, the signalto-noise $(\mathrm{S} / \mathrm{N})$ ratio, and resolution of several electrode arrays through numerical experiments for these two methods.

Recently, reconnaissance surveys of water-covered areas such as rivers, lakes, and coastal bays have been much in demand. The WBE method has good resolving power for vertical structures below the water layer; however, it takes much time and effort to install the electrodes. On the other hand, the conventional floating-electrode method has been used only over small water

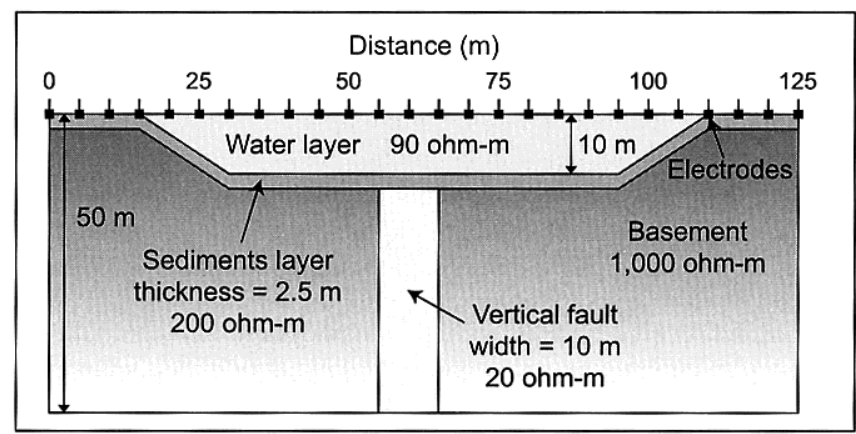

Fig. 1. A schematic diagram of the numerical model for an electrical resistivity survey of a water-covered area. 
bodies, because it has been found difficult to keep the electrode cable straight during measurements. To overcome this problem, a new measuring system was required, which would be capable of continuous resistivity profiling in a quick and convenient way over wide water-covered areas. Snyder and Wightman (2002) and Inoue et al. (2004) designed a new streamer resistivity system, in which electrodes float on the water surface and are towed by a streamer cable from a vessel. They applied it to aquifer characterisation and to imaging of a fresh water spring area.

Even though the streamer resistivity method has already been applied in some real field surveys, there have been few investigations into appropriate electrode spacing, S/N ratio, or resolution of the resistivity images obtained with different electrode arrays. Such studies are essential for survey design, and the interpretation of measured data.

In this study, we have investigated the adaptability of the floating-electrode method by comparing the sensitivity and resolution of resistivity images with those obtained using the WBE method. In addition, we have introduced four kinds of electrode arrays which can be adapted to streamer resistivity surveying, and through numerical testing with a fault-bearing water-covered model, compared the $\mathrm{S} / \mathrm{N}$ ratio and resolving power of those electrode arrays. Finally, we have applied the streamer resistivity method to a survey to delineate a fault zone beneath the riverbed at a planned tunnel site.

\section{NUMERICAL EXPERIMENTS FOR WATER-COVERED AREAS}

Because electrical resistivity responses in water-covered areas are greatly influenced by the water layer, the resistivity and shape of the water layer must be described accurately in the numerical model to get an accurate subsurface image. For numerical experiments, and for inversion of field data, we have used the EM2DModel and DIPROfWin two-dimensional resistivity modelling and interpretation software, developed by the Korea Institute of Geoscience and Mineral Resources (KIGAM). This software is based on 2.5-dimensional finite element modelling, using a Neumann boundary condition for the air boundary at the surface, and mixed boundary conditions for the side and bottom boundaries. The calculated potential values from forward modelling are normalized against applied current value. The smoothness-constrained least-squares inversion scheme adopts Active Constraint Balancing (ACB). The ACB inversion method uses spatially varying Lagrangian multipliers, which are automatically determined from the parameter resolution matrix and Backus-Gilbert spread function analysis (Yi et al., 2003).

In a resistivity survey in a water-covered area, electrodes could be installed on the water bottom, or floated on the water surface. Direct contact with the earth in the former case increases the current into the earth, and sensitivity to subsurface anomalies. However, because it is difficult to install electrodes on the water bottom, it is inefficient for reconnaissance surveys. We have investigated the applicability of electrodes floating on the water surface through numerical experiments, in which we compare the variation in sensitivity and in resolution of resistivity images resulting from the different location of the electrodes, as well as changes in the thickness of the water layer. We have also modelled four kinds of electrode array which can be adapted to streamer resistivity surveys, and compared the signal-to-noise ratio and resolving power of those electrode arrays through similar numerical testing with a fault-bearing water-covered model.

\section{Resolvability of fault anomaly}

In order to compare the sensitivity and resolving power of the floating-electrode and WBE methods, we constructed a watercovered numerical model as shown in Figure 1. The resistivity of the water layer is $90 \Omega . \mathrm{m}$ and the thickness is $10 \mathrm{~m}$, twice the electrode spacing. The vertical fault, with $20 \Omega$.m resistivity, is embedded in a $1000 \Omega$.m basement, below a thin sediment layer with $200 \Omega$.m resistivity. These values are based on borehole log results obtained in Korea as shown later (Fig. 14). The maximum width and depth of the model are $125 \mathrm{~m}$ and $50 \mathrm{~m}$, respectively. The electrode spacing is $5 \mathrm{~m}$, and the cell size of the mesh in forward modelling is $1.25 \mathrm{~m}$ in both $x$ and $z$ directions.

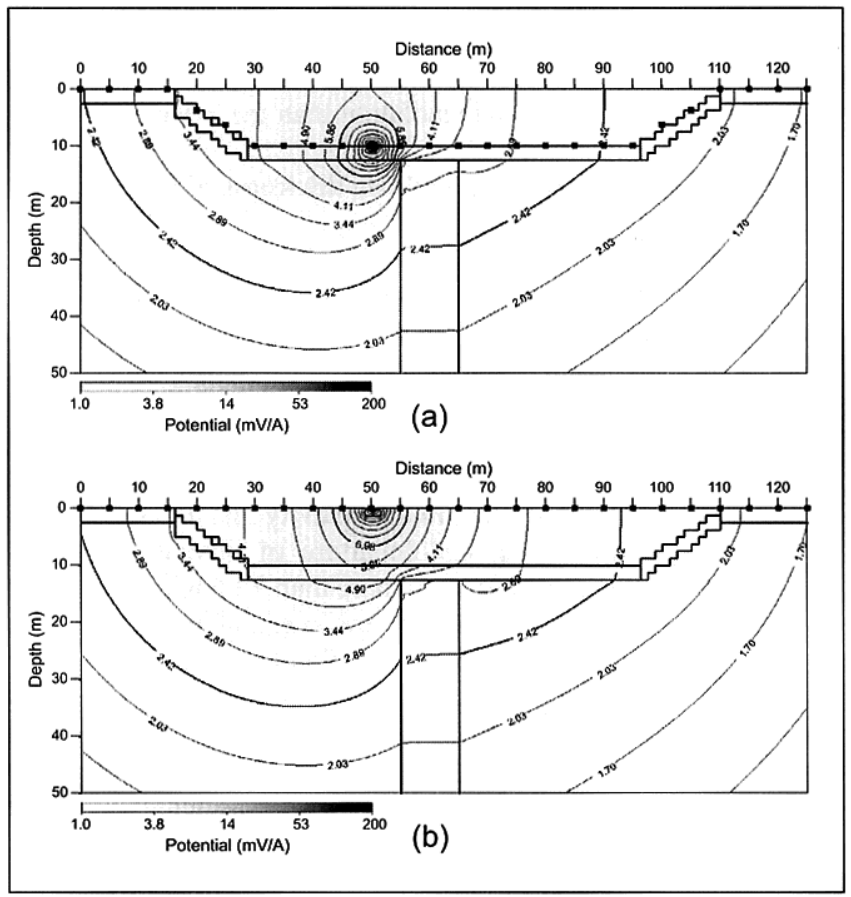

Fig. 2. Potential distributions for the water-covered model shown in Figure 1, when the electrodes are on the water bottom (a), and on the water surface (b). Black points represent the measurement points or electrode positions, and the current electrode is located at $x=50 \mathrm{~m}$ position.

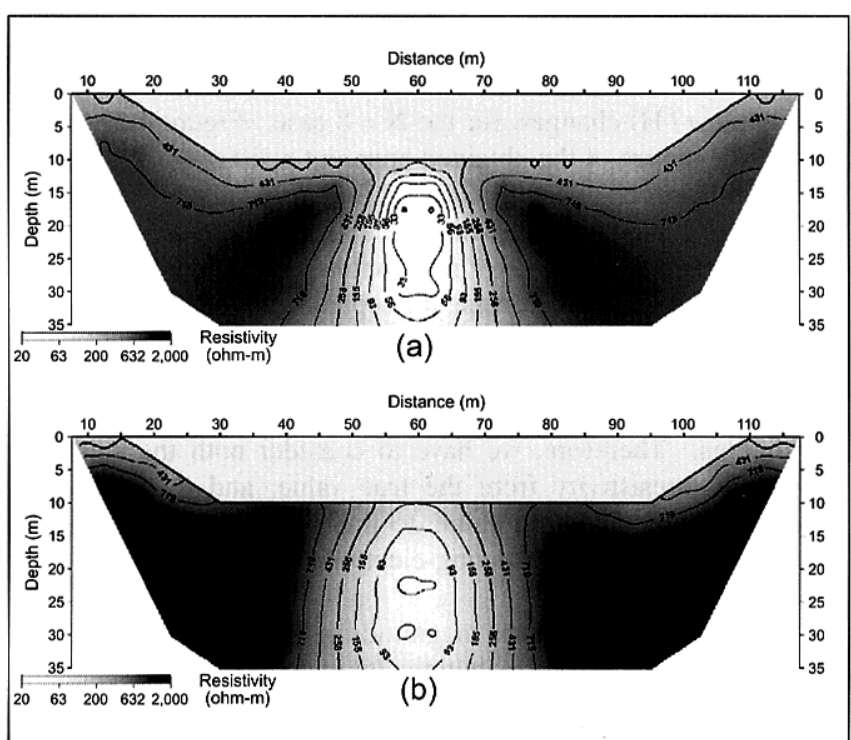

Fig. 3. Subsurface resistivity images by inversion of dipole-dipole array data, for the water-covered model shown in Figure 1, when electrodes are installed on the water bottom (a), and floated on the water surface (b). 
We calculated the potential distribution caused by a single current source located at the $x=50 \mathrm{~m}$ position. Figure 2 shows the potential distribution when the current electrode is on the water bottom (a), or at the water surface (b). Both cases show similar distortion of the potential distribution by the vertical fault, except in the vicinity of the current source.

Figure 3 shows the subsurface resistivity distribution derived by inverting the resistivity data obtained by the WBE method (a) and by the floating-electrode method (b), and these images are clearly similar. The water layer is incorporated into the inversion as a fixed zone with $90 \Omega$.m resistivity, and the dipole-dipole array was modelled in both cases. Both methods show enough resolution down to a depth of about $40 \mathrm{~m}$ from the water surface, although the deeper part of the low-resistivity zone becomes vague. These two numerical experiments suggest that the embedded vertical fault can be imaged by the floating-electrode method, although it has slightly lower sensitivity and resolution than the WBE method.

\section{Minimum electrode spacing and the thickness of the water layer}

The thickness of the water layer is an important factor in the design of a resistivity survey in a water-covered area. A thick water layer may obscure anomalous responses from the deeper rocks. Snyder et al. (2002) calculated apparent resistivity for a dipole-dipole array on a simple homogeneous half-space model covered by a water layer, and examined the difference between apparent resistivity and the true resistivity of the sub-bottom $(\rho-\rho)$. They showed that the departure of observed apparent resistivity from the true value is no more than $50 \%$ when the dipole length is greater than twice of the thickness of the water layer $(a \geq 2 \mathrm{H})$, for a range of 3 to 5 in the ratio of sub-bottom to water layer resistivities $\left(\rho / \rho_{w}\right)$. Since the largest departure was seen at the smallest separation between the dipoles $(\mathrm{N}=1)$, they did not consider apparent resistivities for separations above $\mathrm{N}=2$. Their suggested criterion results in quite large dipole lengths. If we use such large dipole lengths, it may be possible to overcome the effects of a thick water layer, but poor resolution in the inversion image would be an unavoidable outcome.

In this study, we review the minimum electrode spacing for a dipole-dipole array that can detect an anomalous response from beneath the water layer. Initially, we also calculated apparent resistivity for a dipole-dipole array on a simple homogeneous halfspace model covered by a water layer. Figure 4 shows the variation in apparent resistivity as the ratio of dipole length to water-layer thickness $(a / \mathrm{H})$ changes, for the $\mathrm{N}=8$ case. Figure 4 illustrates that the departure of the obtained apparent resistivity $(\rho-\rho)$ is still no larger than $60 \%$ when the dipole length is greater than half of the thickness of water layer $(a \geq 1 / 2 \mathrm{H})$, for the range of the ratio of sub-bottom to water layer resistivities $\left(\rho / \rho_{w}\right)$ from 0.2 to 0.5 and from 2 to 5 . If we increase the separation between the dipoles $(\mathrm{N})$, apparent resistivity departs less from the true value, which leads to a lower criterion for dipole length. However, the measured potential value also decreases with increasing separation between the dipoles. Therefore, we have to consider both the departure of apparent resistivity from the true value, and the magnitude of the measured potential value, to find a criterion for minimum electrode spacing in the floating-electrode method.

In order to investigate the magnitude of the response to the fault, we computed potential distributions for two water-covered models, one with a vertical fault in basement, and the other without. The models are exactly the same as shown in Figure 1 except for the thickness of water layer. A dipole-dipole array was modelled, with electrodes on the water surface at $5 \mathrm{~m}$ spacing. We then calculated the difference between the two potential distributions,

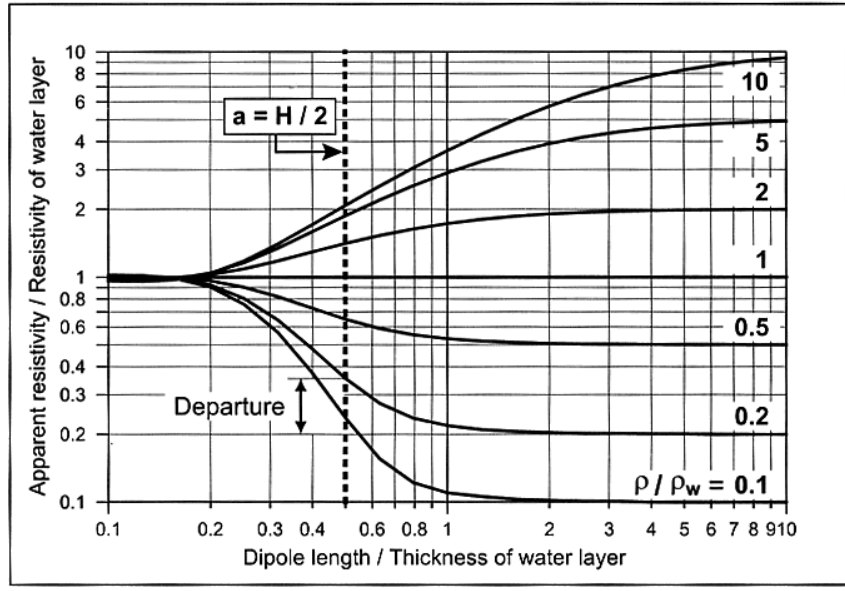

Fig. 4. Two-layer apparent resistivity curves for a dipole-dipole array as a function of the ratio of dipole length to the thickness of water layer, when the electrode separation index is 8 .

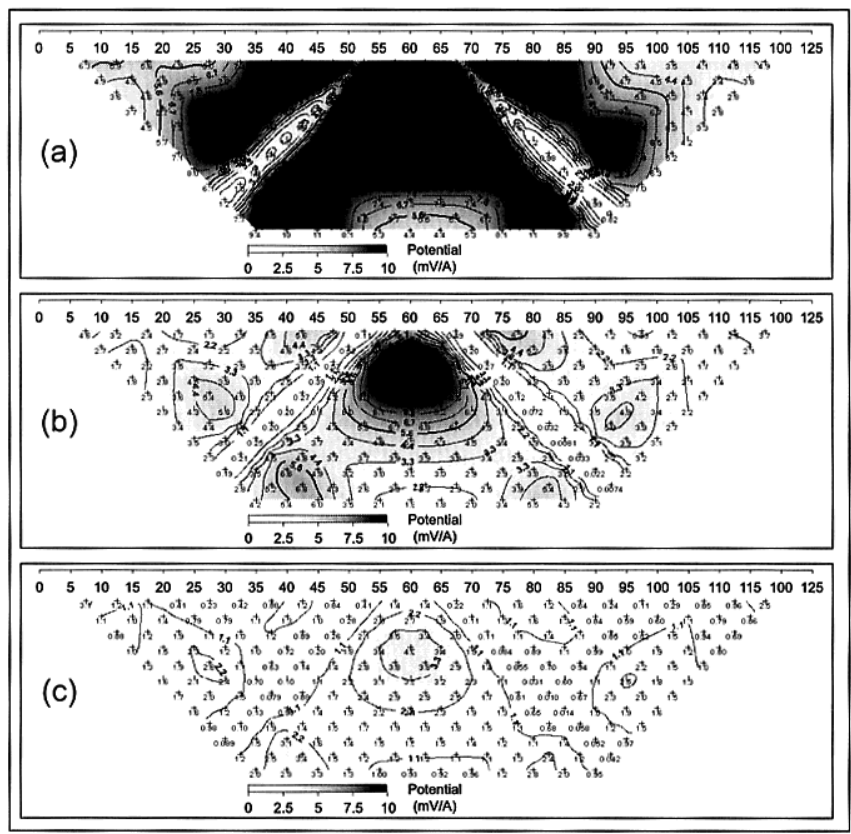

Fig. 5. Potential-difference pseudosections for a dipole-dipole array on the water-covered model shown in Figure 1, with three different waterlayer thicknesses. The potential difference values are of the difference between the two potential fields calculated for a model with a vertical fault and a model without the fault. (a) Thickness of water layer = $5 \mathrm{~m}(\mathrm{a} / \mathrm{H}=1)$. (b) Thickness of water layer $=10 \mathrm{~m}(\mathrm{a} / \mathrm{H}=1 / 2)$. (c) Thickness of water layer $=15 \mathrm{~m}(\mathrm{a} / \mathrm{H}=1 / 3)$

and displayed the results as potential-difference pseudosections as shown in Figure 5. Figure 5 illustrates a gradual decrease in the effect of the vertical fault as the water-layer thickness increases. When the water-layer thickness is $5 \mathrm{~m}$, equal to the electrode spacing $(a / \mathrm{H}=1)$, the difference in responses is more than 10 mV/A at all positions and at large dipole separations $(\mathrm{N}>12)$. Moreover, the responses near the fault still differ by more than $5 \mathrm{mV} / \mathrm{A}$ at the dipole separations up to $\mathrm{N}=8$, for a water layer thickness of $10 \mathrm{~m}(a / \mathrm{H}=1 / 2)$. However, the difference between responses falls to environmental noise levels for $a / \mathrm{H}=1 / 3$. These two experiments suggest that electrode spacing should be more than half of the water-layer thickness $(a \geq 1 / 2 \mathrm{H})$ to image a fault using the floating-electrode dipole-dipole array. 


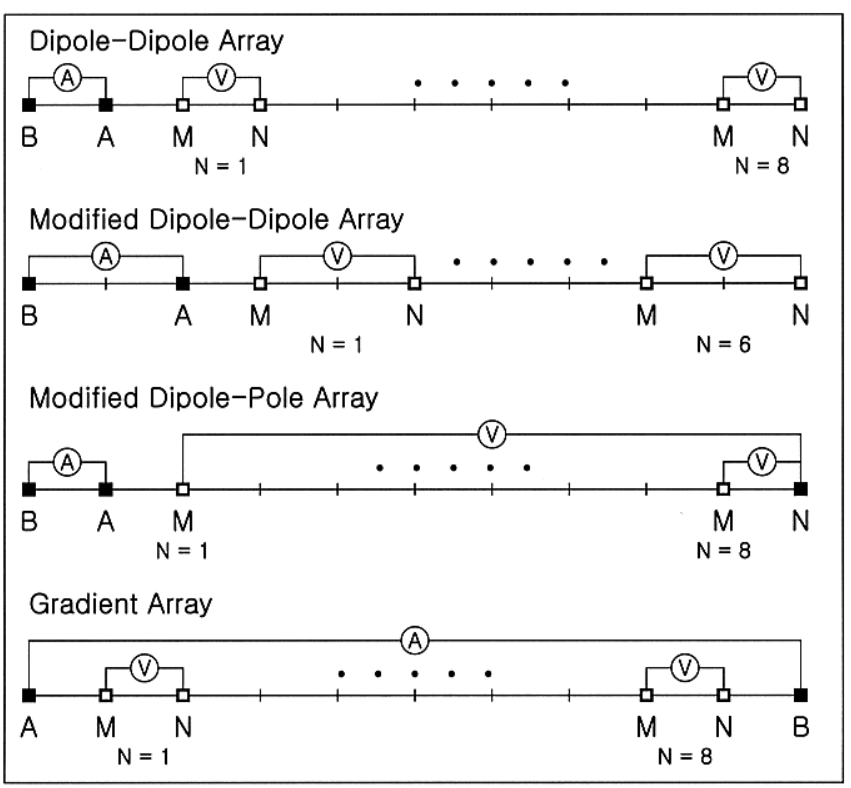

Fig. 6. Schematic diagrams of the four kinds of electrode arrays that can be adapted for the streamer resistivity survey. The streamer cable consists of 11 electrodes. The electrodes represented by black rectangles are fixed, for a particular source point, while those represented by white rectangles are shifted to the right as the electrode separation index is increased.

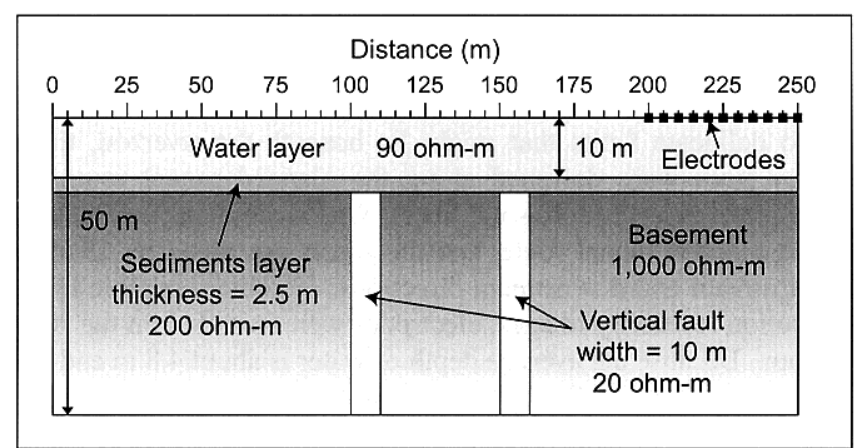

Fig. 7. A schematic diagram of the numerical model for testing the signal-to-noise ratio and resolving power of four electrode arrays.

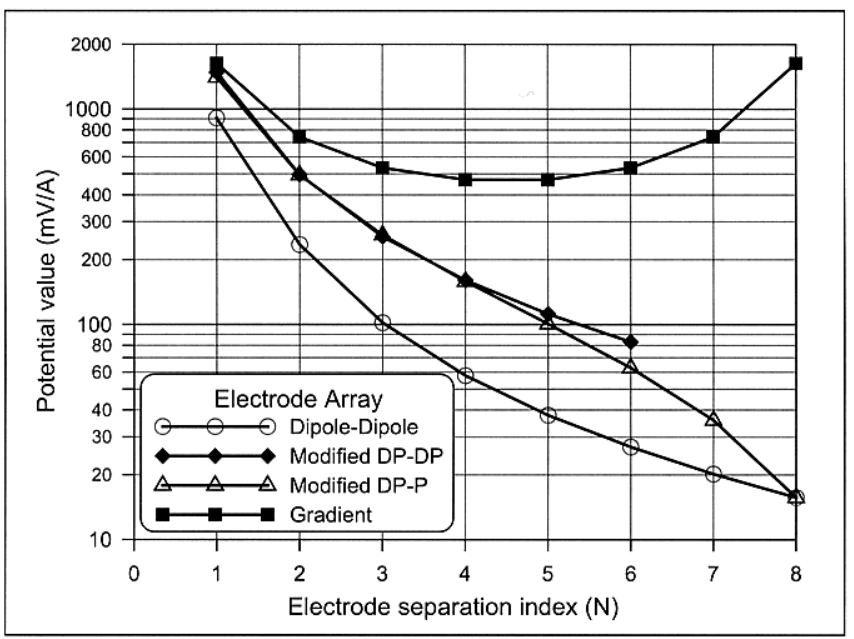

Fig. 8. Potential curves of four electrode arrays, as the electrode separation index is increased, for the water-covered model shown in Figure 7 but without faults in the basement.

\section{Electrode arrays for streamer resistivity surveys}

Streamer resistivity surveys, using electrodes in a streamer cable towed by ship or boat, cannot make use of some electrode arrays, such as pole-pole, pole-dipole, or dipole-pole, which require fixed, remote electrodes. In addition, to conduct continuous resistivity profiling, we should measure potentials at several electrodes at the same time for each current source. Schlumberger or Wenner arrays are therefore not appropriate, because these methods require that the current electrodes be moved when increasing the depth of investigation of the array.

In this study, we compare the signal-to-noise ratio and resolving power of four electrode arrays that can be adapted to streamer surveys. Figure 6 shows schematic diagrams of the four arrays; dipole-dipole, modified dipole-dipole, modified dipole-pole, and gradient array. In this numerical experiment, we assume that the streamer cable consists of 11 electrodes, so that we can measure up to eight potential data at the same time, for a single current (dipole or bipole) source. The modified dipole-dipole array has a similar configuration to the conventional dipole-dipole array except that the dipole length is greater than the minimum dipole offset. The modified dipole-pole array is a new technique in which the remote potential electrode in a conventional dipole-pole array is placed at the end of the streamer cable (Kim et al., 2001). In the gradient array, which is a variation of the Schlumberger array, the distance between the potential electrodes is usually kept to less than $1 / 10$ the distance between the current electrodes. The gradient array, normally used only for profiling, is known to be superior for lateral location of steeply dipping inhomogeneities, and for resolving two adjacent conductors (Coggon, 1973).

In selecting an electrode array, we always must compromise between the improving the signal-to-noise ratio and improving the resolving power. These two characteristics are the most important criteria for choosing an electrode array. For our test we composed the water-covered numerical model shown in Figure 7. Two vertical faults, each $10 \mathrm{~m}$ in width, are embedded in basement below a thin sediment layer; the horizontal locations of these faults are $100-110 \mathrm{~m}$ and $150-160 \mathrm{~m}$. The maximum width and depth of the model are $250 \mathrm{~m}$ and $50 \mathrm{~m}$, respectively. The electrode spacing is $5 \mathrm{~m}$, and the cell size of the mesh in forward modelling is 1.25 $\mathrm{m}$ in both $x$ and $z$ directions. The streamer cable has 11 electrodes and commences at the right side of the water surface and moves to the left. For each current source point, we measure six or eight potential data.

Figure 8 shows potential curves of the four electrode arrays, as a function of the electrode separation index $(\mathrm{N})$, for a watercovered model similar to that shown in Figure 7, but without the faults in basement. These potential curves give us the variation of the signal-to-noise ratio of the four arrays for a one-dimensional layered earth which consists of a water layer, a thin sediment layer and basement. The gradient array shows the highest potential value, because it has the largest distance between the current electrodes, while the dipole-dipole array shows the lowest value. The modified dipole-pole array shows similar behavior to the modified dipole-dipole array up to $N=4$. As the electrode separation index increases, however, the response of the modified dipole-pole array falls more rapidly than that of the other arrays. Figure 8 illustrates that the gradient array is the best choice for signal-to-noise ratio, and the next choices are modified dipoledipole, modified dipole-pole, and dipole-dipole, in turn.

To investigate the resolving power of the arrays, we carried out further numerical experiments using the water-covered model shown in Figure 7. To simulate field measurements, we contaminated the calculated potentials with random electrical noise with $\pm 5 \mathrm{mV} / \mathrm{A}$ 


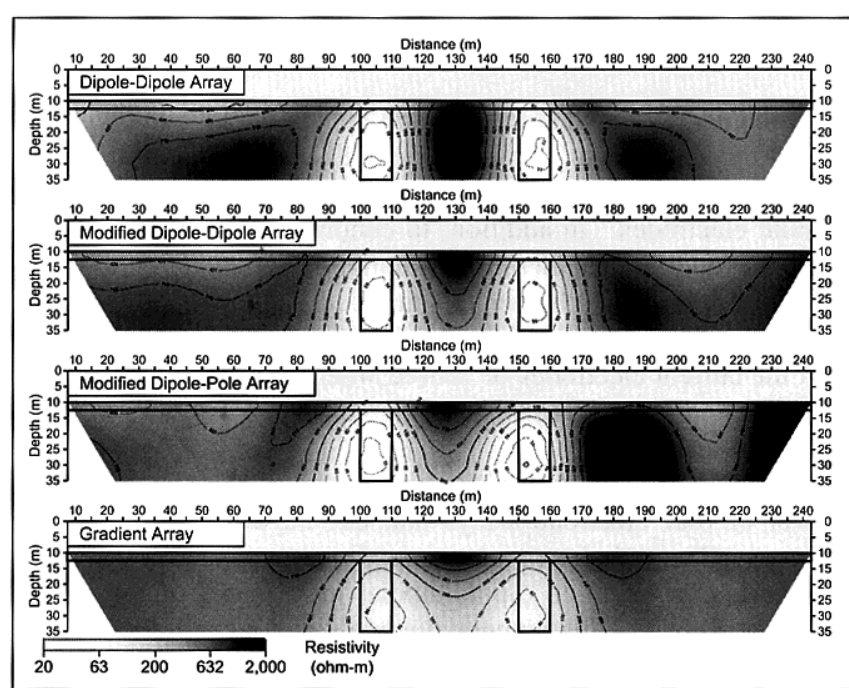

Fig. 9. Subsurface resistivity images from inversion of data calculated for four electrode arrays for the water-covered model shown in Figure 7. The calculated potential used for inversion is contaminated with random noise having $\pm 5 \mathrm{mV} / \mathrm{A}$ peak-to-peak amplitude, and each observation is the result of 2 stacks.

peak-to-peak amplitude, and stacked two measurements for each data point. We again applied the smoothness-constrained leastsquares inversion algorithm, including the ACB method, to the simulated data, and incorporated the water layer into the inversion as a fixed component with $90 \Omega . m$ resistivity and $10 \mathrm{~m}$ depth.

Figure 9 demonstrates the inverted resistivity images for each electrode array. The resistivity image for the dipole-dipole array not only clearly shows the locations of the vertical faults but also approximates the resistivity value of the basement. The images for modified dipole-dipole and modified dipole-pole array data show poorer resolution of the faults. (A high-resistivity artefact at $x=180 \mathrm{~m}$ in the image inverted from modified dipole-pole array data is caused by the asymmetry of this array.) The gradient array shows the least resolution of the vertical faults, because the least separation between the current and potential electrodes gives the least penetration depth. Because of the masking effect of the thick,

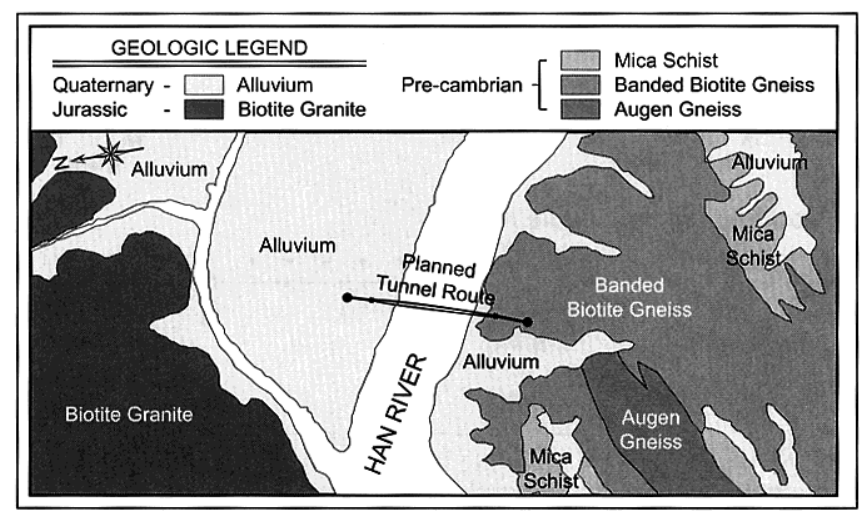

Fig. 10. Geological map of survey area on the Han River in Seoul, Korea.

conductive water layer, none of the resistivity images could clearly delineate the sediment layer.

\section{ELECTRICAL RESISTIVITY SURVEY USING ELECTRODES ON THE WATER BOTTOM}

We have carried out a electrical resistivity survey of the site for a planned tunnel beneath the Han River in Seoul, Korea. The rocks of this area are divided into two types: Precambrian metamorphic rocks consisting of mica schist, banded biotite gneiss, augen gneiss and so on; and Jurassic granite. A thick cover of Quaternary fluvial deposits is formed on the alluvial plains beside the Han River and its tributaries (Figure 10).

To delineate faults that might lie beneath the riverbed, three survey lines were designed along the planned tunnel route, as shown in Figure 11 (bold solid lines). One is along the central axis of the planned tunnel route, and the others are offset by $15 \mathrm{~m}$ in the upstream and downstream directions. To obtain reliable highresolution resistivity images, electrodes were installed on the river bottom. Because the average depth of water is about $4.8 \mathrm{~m}$ and the maximum reaches $5.7 \mathrm{~m}$, we adopted a dipole-dipole array with $5 \mathrm{~m}$ electrode spacing. Waterproof electrode cables were installed on the water bottom by scuba divers, using Differential Global

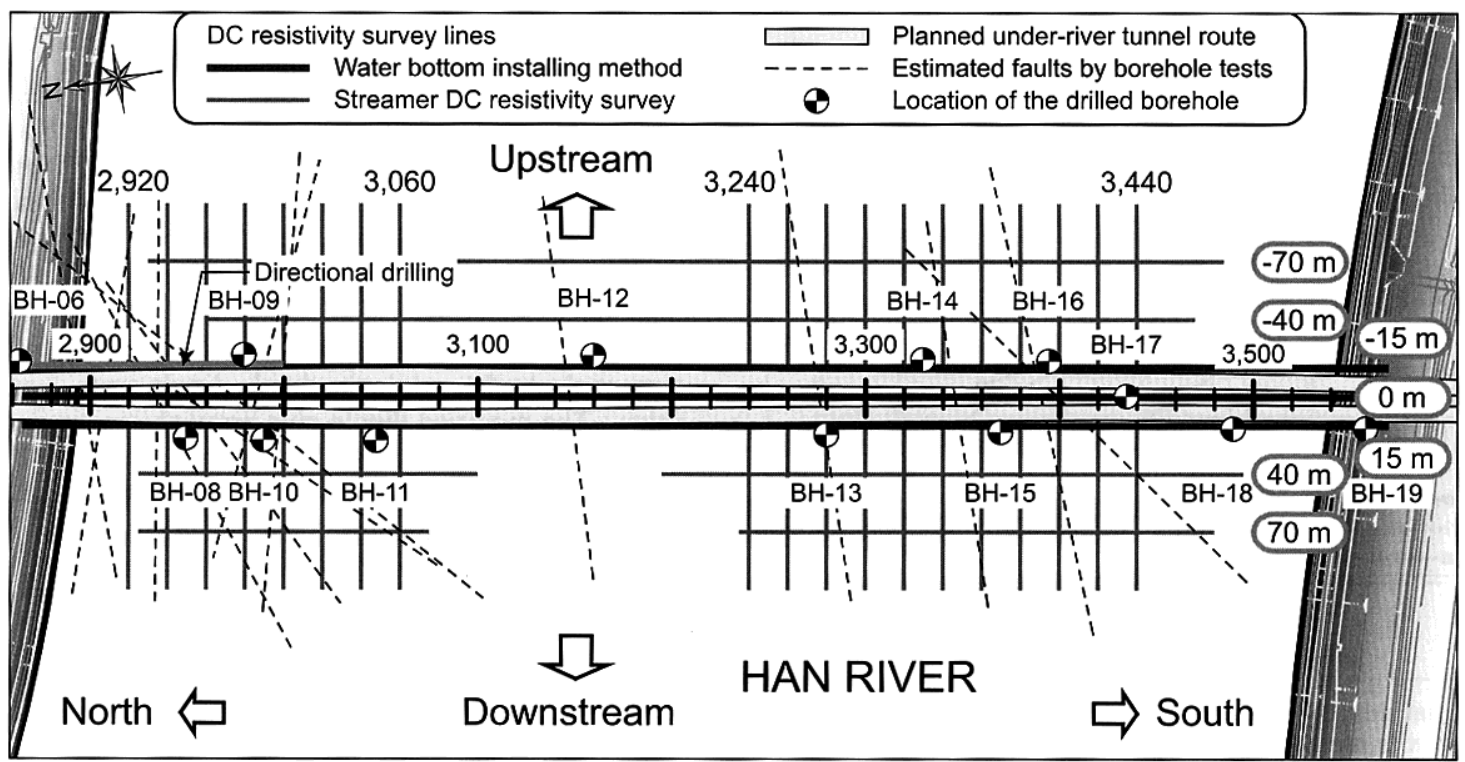

Fig. 11. Location map of the resistivity survey lines. There are 7 lines parallel to, and 19 orthogonal to, the planned tunnel route. The WBE method is applied on the central three (bold) lines, and the streamer method is applied on the others. 


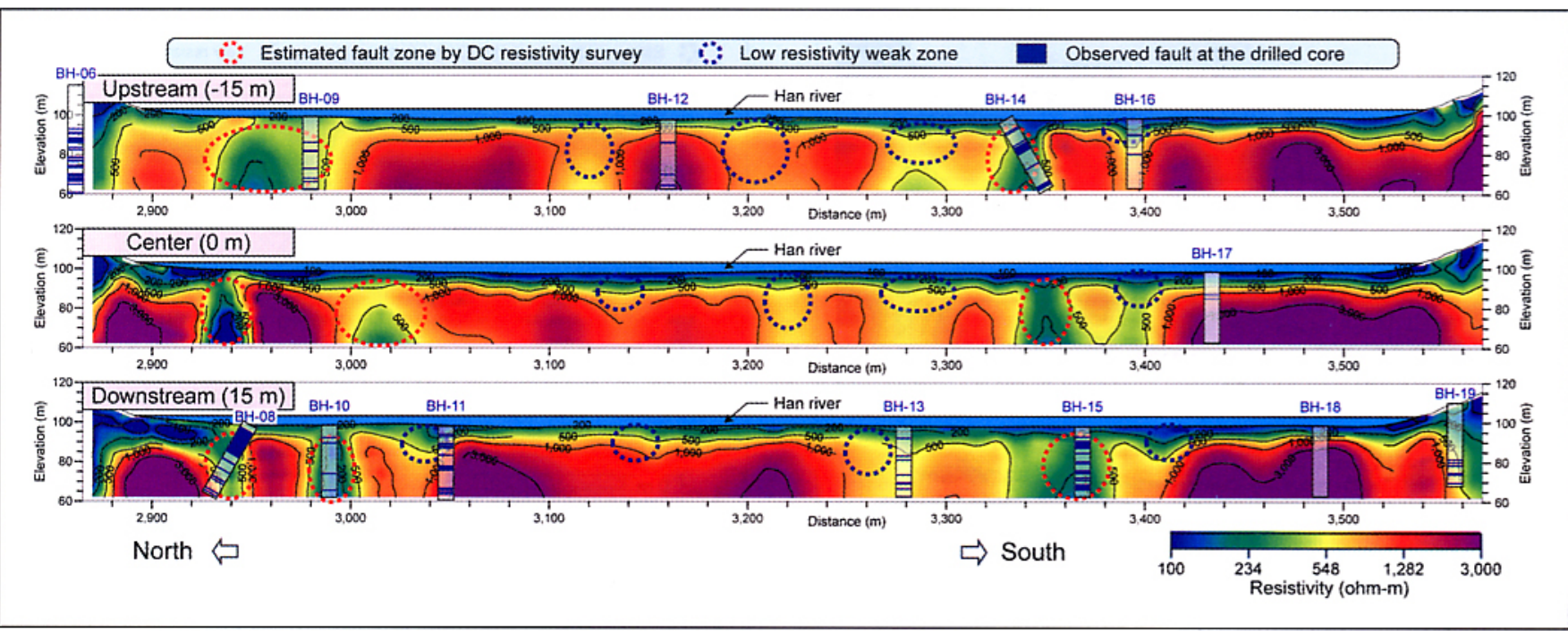

Fig. 12. Three subsurface resistivity images obtained by the WBE method. The interpreted low-resistivity weak zones are superimposed on the inversion image as dashed circles. Fault zones observed in core samples from boreholes are shown as columnar sections.

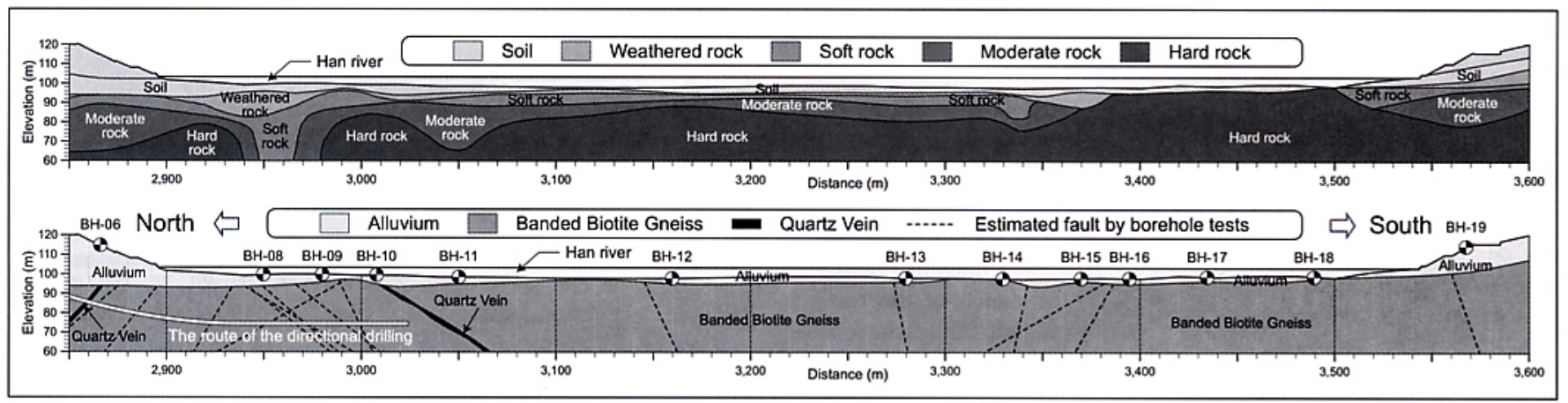

Fig. 13. Cross-section view of the rock classification (upper) and geology (below) interpreted from borehole log data and borehole tests.

Positioning System (DGPS) for accurate locating of the electrodes. As a measurement system, we used a Supersting R8IP with Swift box manufactured by Advanced Geosciences, Inc., USA. The conductivity and depth of the water along the survey lines were also measured, by digital conductivity meter and multi-beam echo sounder respectively.

Resistivity data, and other information obtained during the survey, were used to construct an image of the subsurface below the riverbed. Our inversion results, with some interpretation, are displayed in Figure 12. The overall resistivity values derived by inversion range from 100 to $5000 \Omega$.m. Below $10 \mathrm{~m}$ depth, except for some anomalous zones, the subsurface has resistivities of more than $1000 \Omega . m$, which we interpret as fresh rock. In the resistivity images of the three survey lines, we also see two or three distinct low-resistivity anomalies, with resistivities below $200 \Omega \mathrm{m}$, in the intervals between $2920-3040 \mathrm{~m}$ and $3320-3380 \mathrm{~m}$. In addition, there are four zones in which resistivity ranges from 200 to $1000 \Omega$.m which appear on all three lines, and which we interpret as weak zones. All of these low-resistivity anomalies clearly show some connection in the east-west direction, along the river.

Based on the results of the resistivity survey, we chose locations for borehole drilling (Figure 11). To confirm the cause of lowresistivity anomalies, in particular, two inclined boreholes were drilled into the low-resistivity anomalous regions on the resistivity images. Through naked-eye examination of recovered core, we observed ample evidence of faulting, such as fault gouge, fault breccia, and slickensides. The observations suggest that the faults dip steeply, at more than $60^{\circ}$, and that the maximum width of the fault zones reaches $14 \mathrm{~m}$. To aid interpretation, we superimposed the depth and width images of faults on the resistivity sections. As shown in Figure 12, the locations of the distinctive anomalous region coincide with those of observed fault zones several metres in width. Thus, three low resistivity anomalies below $200 \Omega . m$

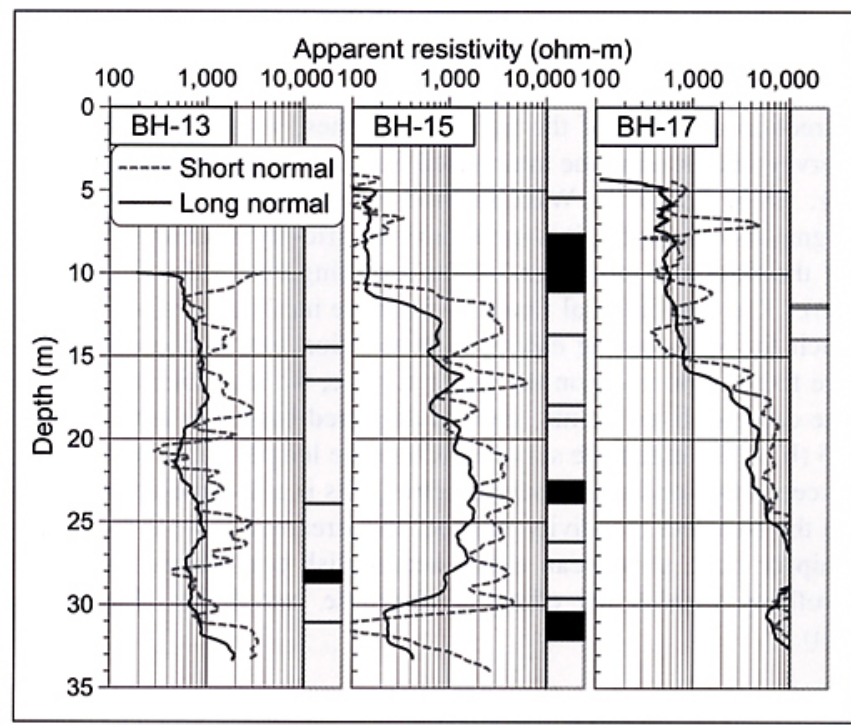

Fig. 14. Electrical resistivity logs (short normal and long normal resistivity) measured in boreholes $\mathrm{BH}-13, \mathrm{BH}-15$, and $\mathrm{BH}-17$. Fault zones observed in core samples from boreholes are shown as columnar sections on the right side of the resistivity log curves. 


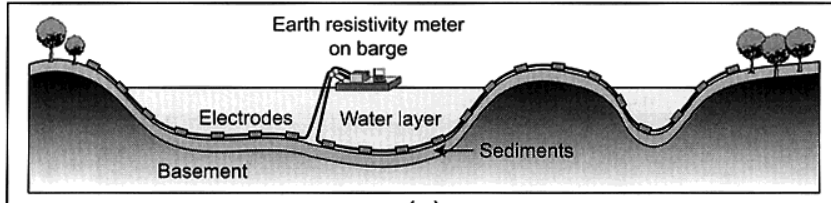

(a)

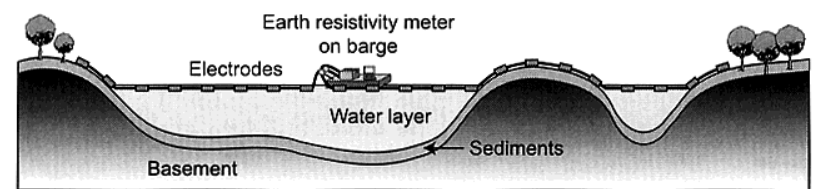

(b)

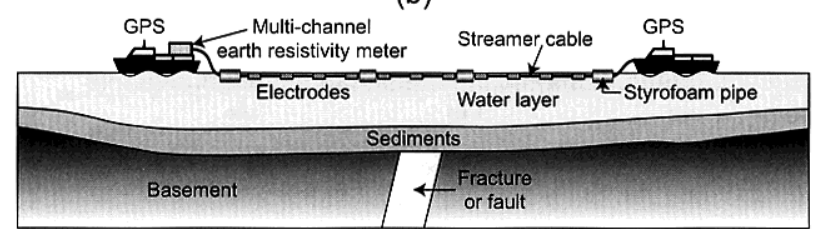

(c)

Fig. 15. Schematic diagrams of alternative layouts for electrical resistivity surveys in water-covered areas. (a) WBE method (b) floating-electrode method (c) streamer resistivity method

could be interpreted as main fault zones that are the weakest zones in this site.

In order to obtain the strike direction of the faults, we carried out in-situ borehole tests such as acoustic and optical scanning, and the resulting estimated faults are illustrated by dashed lines in Figures 11 and 13. Figure 13 shows a cross-section sketch of the rock classification (upper) and geology with estimated faults (lower), interpreted from borehole log data and borehole tests. Specifically, the detailed information about faulting in the northern part of survey area was obtained through directional drilling along the planned tunnel route, and optical borehole-scanning tests in the interval from $2780 \mathrm{~m}$ to $3020 \mathrm{~m}$ (Figure 11). Figure 14 shows electrical resistivity logs measured at boreholes $\mathrm{BH}-13, \mathrm{BH}-15$, and $\mathrm{BH}-17$. As shown in Figure 14, the resistivity of fresh rock is higher than $500 \Omega . \mathrm{m}$, while resistivity in the fault zone falls below $200 \Omega$.m.

\section{STREAMER RESISTIVITY SURVEY}

In the previous section, we have shown that a resistivity survey effectively provides subsurface images that assist the location of faults or weak zones in water-covered areas. In order to obtain the direction of strike of the main fault zones, we require grid-style survey lines around the interpreted weak zones, as shown in Figure 11. Even though the WBE method has good resolving power and signal-to-noise ratio, it is inefficient for grid-style surveys, because of the time and effort needed for installing electrodes (Figure 15 (a)). The conventional floating-electrode method does not require such time-consuming electrode installation but, as the electrodes are fixed in position on the water surface, we must tie the ends of the cable to fixed points, such as anchored barges or land (Figure 15 (b)). For extensive surveys, where the length of the survey line exceeds two or three hundred metres, this is also time-consuming. In the streamer resistivity method, the streamer cable is towed by ship or boat, so we can easily accomplish continuous resistivity profiling without the effort of electrode installation (Figure 15 (c)).

The streamer resistivity method is suitable for reconnaissance surveys (Snyder et al., 2002), so we implemented that for the Han River study. We devised a waterproof streamer cable that is approximately $100 \mathrm{~m}$ in length and which contains 19 electrodes at uniform $5 \mathrm{~m}$ spacing, to be towed by boat. We attached Styrofoam

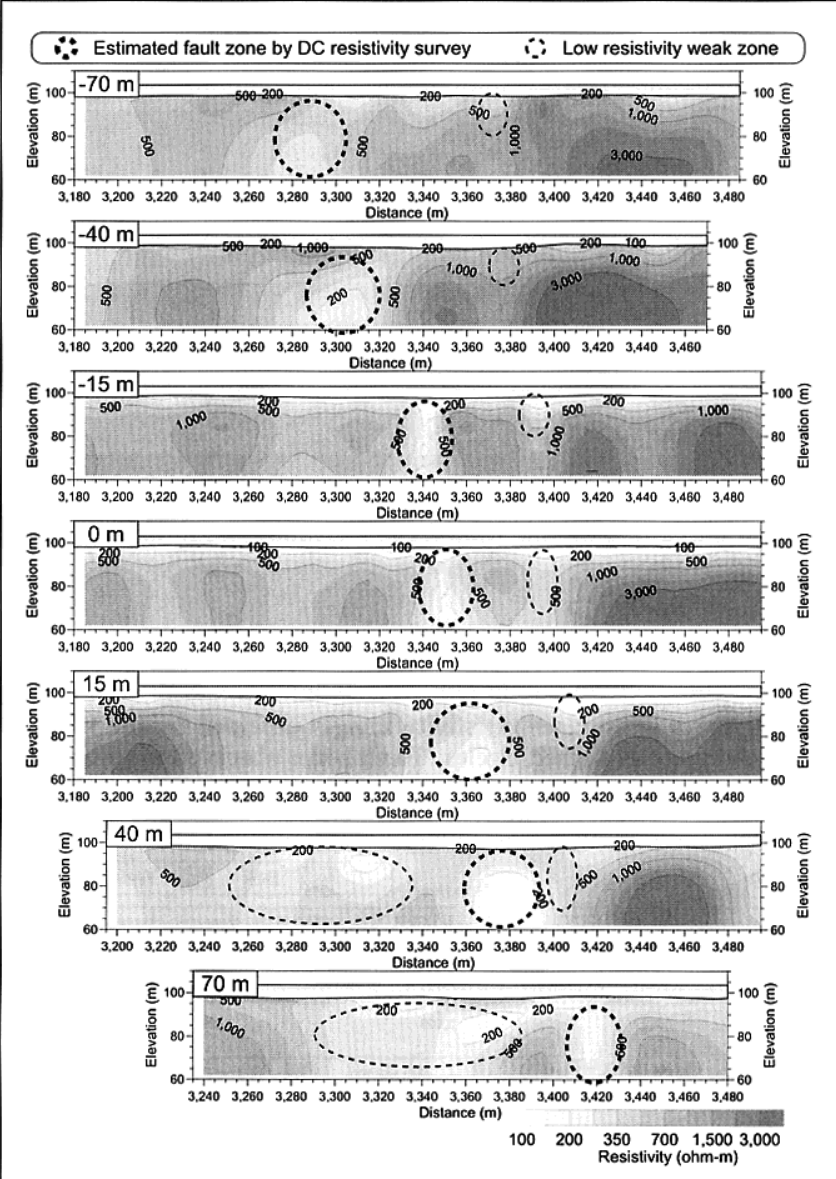

Fig. 16. Comparison of images from inversion of electrical resistivity data from the WBE method $(-15,0$, and $15 \mathrm{~m})$ and the streamer method $(-70,-40,40$, and $70 \mathrm{~m})$. These images are from survey lines parallel to the planned tunnel route, offset upstream or downstream by the stated distances.

pipe to the streamer cable so that the electrodes floated just below the water surface as shown in Figure 15 (c). To navigate the boat, and record electrode positions at the moment of each measurement, a Differential GPS system with several-decimetre accuracy was installed on the boat. A digital conductivity meter and a hand-held Fathometer were also used to record the conductivity and the depth of water at each measurement position.

To conduct continuous resistivity profiling, a high-speed multichannel measurement system is essential, and we used a Supersting R8IP system, with Swift box. This instrument measures eight potential data simultaneously. Because the average depth of water was close to the electrode spacing, we adopted the dipole-dipole array. Maximum available current was transmitted to reduce measurement time and number of stacks required. With transmitted current of $350 \mathrm{~mA}$, reliable data quality was produced with a 3.6 second measuring time and no stacking at each data point, and data could be acquired at about 6.5 second intervals. With the towing vessel navigating at a speed of $35 \mathrm{~m} / \mathrm{min}$, the effective measuring interval was about 4 metres.

Unlike normal resistivity surveys, the measuring points in a streamer survey may have some deviation from the planned straight line. In addition, because we measure data at regular intervals of time, not distance, the distance between each measuring point varies with the speed of vessel. Some processing of the measured data is therefore required before inversion is carried out. In the processing stage, first, we determined the electrode position and water depth for all measurements. Second, all the measured data 


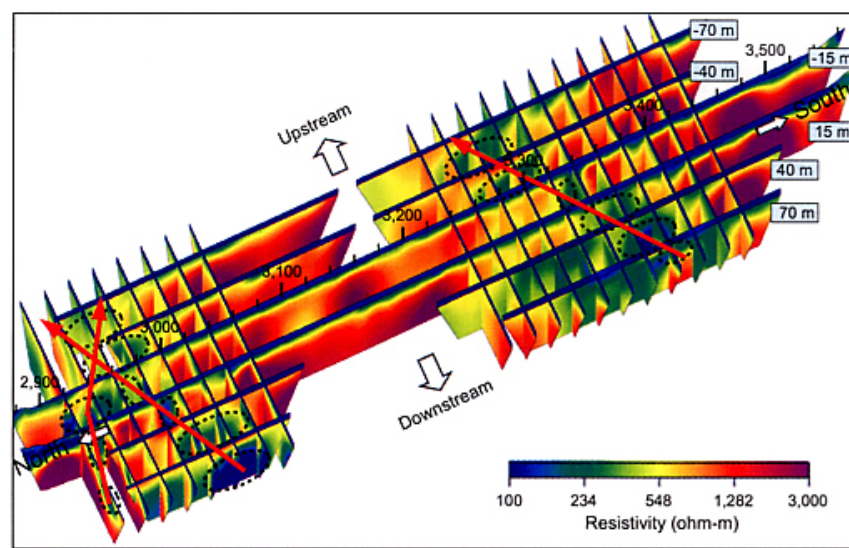

Fig. 17. Three-dimensional fence diagram made from streamer-method resistivity images. The two central lines are from the WBE method, while the remainder are from the streamer survey. The diagram clearly shows the extent and direction of three distinct weak anomalous zones.

were projected onto the planned survey line on the assumption that there is no severe horizontal (cross-line) variation in resistivity. At this stage we eliminated some data that were projected beyond the planned survey line. Next, we calculated evenly spaced apparentresistivity values and water depths using numerical interpolation, which was essential for input to the inversion scheme. Finally, we constructed a subsurface resistivity image by two-dimensional inversion with the water layer parameters fixed.

In order to demonstrate the reliability and resolution of the inversion result produced from the streamer survey, we compare images of the inversion results from this method with those from the WBE method (Figure 16). In Figure 16, the central three images, at $-15,0$, and $15 \mathrm{~m}$, are obtained from the WBE method, while all the other images are from the streamer survey. As Figure 16 shows, although the resolution of the streamer method is lower than that of the WBE method, the inversion images clearly and consistently show the existence of the low-resistivity anomalies in almost all sections.

For more efficient interpretation, we combined all the inversion images from the streamer survey using a three-dimensional fence diagram (Figure 17). We included the inversion results for four longitudinal and 19 latitudinal streamer-survey lines,

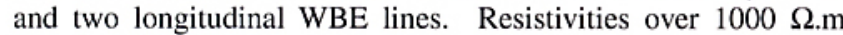
at the two banks, and in the central part of the riverbed, are consistently delineated in most inversion sections. Moreover, the low-resistivity anomalous regions (resistivity less than $200 \Omega$.m) are clearly imaged in almost all sections. The interpreted weak zones are developed in an east-west direction which matches very well with the strike direction of faults predicted by borehole observations. We can, however, more easily discern the direction and extent of faulting using the pseudo three-dimensional grid images derived from the streamer resistivity survey.

\section{CONCLUSIONS}

In water-covered areas such as rivers or lakes, the WBE resistivity method is suitable for detailed surveys because of its high resolving power, but the streamer resistivity method, with electrodes floating on the water surface, is efficient for reconnaissance surveys as continuous resistivity profiling gives rapid field coverage.

Actual field work with the streamer method needs precise positioning of the electrodes and high-speed measurement of potential data, so we have designed a boat-towed resistivity measuring systemby assembling appropriate electronic measurement devices. This new system consists of a waterproof streamer cable, a multi-channel resistivity instrument, DGPS, a digital conductivity meter, and a hand-held Fathometer. We have also devised data processing techniques to allow data measured at actual locations to be projected onto evenly spaced points on a straight survey line, for two-dimensional inversion and interpretation.

With the Han River case study, we have demonstrated that the streamer resistivity survey is a powerful tool to produce a continuous subsurface resistivity image of a water-covered area in a quick and economical way. In particular, the streamer method effectively reduces the time and effort required for threedimensional resistivity surveys in water-covered areas.

\section{ACKNOWLEDGEMENTS}

We sincerely thank Dr. Soon Jee Seol for her valuable assistance and comments toward improving the quality of this paper.

\section{REFERENCES}

Cho, S.-J., Kim, J.-H., Yi, M.-J., Lee, S.K., Son, J.-S., and Sato, M., 2004, Effective methodology of DC resistivity survey for imaging the underground structure at water-covered area: Proc. 110th SEGJ Conference, 180-183.

Chung, H.-J., Kim, J.-H., Park, K.-P., Kwon, H.-S., Choi, H.-S., Kim, K.-S., and Kim, J.-S., 2001, Application of geophysical results to designing bridge over a large fault: Geotechnical Problems in Asian Countries, Proceeding of Fourth Asian Young Geotechnical Engineers Conference, 45-48.

Coggon, J.H., 1973, A comparison of IP electrode arrays: Geophysics, 38, 737-761.

Fuji-ta, K., and Ikuta, O., 2000, Resistivity structure of the central part of the Yamasaki fault studied by the multiple electrodes resistivity method: Earth Planets Space, 52, 567-571.

Inoue, M., Sasaki, M., and Hachino, Y., 2004, Improvements of the sea bottom electro sounding system: Proc. 110th SEGJ Conference, 63-66.

Kim, J.-H., Yi, M.-J., Song, Y., and Chung, S.-H., 2001, A study on the modified electrode arrays in two-dimensional resistivity survey: Mulli-tamsa, 4, 59-69 (in Korean with English abstract).

Kim, J.-H., Yi, M.-J., Song, Y., Cho, S.-J. Chung, S.-H., and Kim, K.-S., 2002a, DC resistivity survey to image faults beneath a riverbed: Symposium on the Application of Geophysics to Engineering and Environmental Problems (SAGEEP), 13IDA10.

Kim, J.-H., Yi, M.-J., Song, Y., Cho, S.-J., Lee, S.K., Son, J.-S., and Chung, S.-H., $2002 \mathrm{~b}$, A study on the DC resistivity method to image the underground structure beneath river or lake bottom: Mulli-tamsa, 5, 223-235 (in Korean with English abstract).

Snyder, D.D., MacInnes, S.C., Raymond, M.J., and Zonge, K.L., 2002, Continuous resistivity profiling in shallow marine and fresh water environments: Symposium on the Application of Geophysics to Engineering and Environmental Problems (SAGEEP), 13GSL4.

Snyder, D.D., and Wightman, W.E., 2002, Application of continuous resistivity profiling to aquifer characterization: Symposium on the Application of Geophysics to Engineering and Environmental Problems (SAGEEP), 13GSL10.

Unsworth, M.J., and Bedrosian, P.A., 2004, Electrical resistivity structure at the SAFOD site from magnetotelluric exploration: Geophys. Res. Lett., 31, L12S05, doi:10.1029/2003GL019405.

Yi, M.-J., Kim, J.-H., and Chung, S.-H., 2003, Enhancing the resolving power of leastsquares inversion with active constraint balancing: Geophysics, 68, 931-941. 


\section{ストリーマー電気探查による川底下の断層の検出 \\ Hyoung-Seok Kwon ${ }^{1} \cdot$ Jung-Ho Kim ${ }^{2} \cdot$ Hee-Yoon Ahn ${ }^{3}$ • Jin-Sung Yoon ${ }^{3}$ \\ Ki-Seog Kim ${ }^{3} \cdot$ Chi-Kwang Jung $^{4} \cdot$ Seung-Bok Lee ${ }^{5} \cdot$ 内田利弘 ${ }^{1}$}

要 旨：川底の地盤には断層带など脆弱部が存在する可能性が非常に高いが、河川水があるため地表地質調查は難しく、 川底下の断層帯を把握することは容易ではない。その意味で、水面上や川底で行う電気探査（以下、水上電気探查という）は、 川底地盤の連続的な比抵抗構造を得ることができるので、断層や脆弱部の位置を把握するために非常に效果的な探查法である。 川底にトンネルを建設する場合、断層帯の位置だけではなく断層帯の走向方向が重要な要素となる。断層帯の走向を把握する には格子状に測線を配置し、広域の調查を行うのが効果的である。従来の水上電気探査は電極やケーブルを川底に設置するの で広域調查には向かない。本論文では、小型ボートでストリーマーケーブルを曳航して広域を迅速に調查することのできるス トリーマー電気探查について、川底下のトンネル建設予定地への適用性を考察した。

ストリーマー電気探査による断層带の探査分解能を考察するために、垂直断層が川底下の堆積層に稪われているモデルにつ いて数值実験を行った。電極の設置位置と水深を変化させ、垂直断層の探䍒分解能を調べた。その結果、水深が電極間隔の 2 倍以内の場合には、電極を水面上に設置する方式でも川底下の垂直断層を解析できることがわかった。また、4 通りの電極配 璪について $\mathrm{S} / \mathrm{N}$ 比と垂直断層の分解能を比較し、ストリーマー電気探査に適する電極配置を検討した。数值実験結果を参考と し、韓国ソウル市を流れる漢江の川底トンネル建設予定地において水上電気探查を実施した。トンネル予定路線では高分解能 の比抵抗構造が要求されるので、まず、川底に電極を設置する方式で測定を行い、2 次元インバージョンによって断層と推定 される $3 つ の$ 低比抵抗異常帯を把握した。低比抵抗異常帯の原因を調べるためボーリング調查を行い、数 $\mathrm{m}$ 以上の幅を持つ多 数の断層の存在を確認した。断層带の走向方向を解明するため、確認された低比抵抗異常帯を中心に格子状の測線を設定し、 ストリーマー電気探査を実施した。川底にケーブルを設置する方式に比べて非常に迅速で経済的な測定が行え、また、川底に 分布する異常带の分布範囲と発達方向を把握することができた。

\section{스트리머 전기비저항 탐사에 의한 하저 단층 탐지 권형석 1 - 김정호 $2 \cdot$ 안희윤 $3 \cdot$ 윤진성 3 김기석 3 - 정치광 4 - 이승복5 - Toshihiro Uchida ${ }^{1}$}

요 약: 하저지반은 단총대의 분포가능성이 매우 높으나 수층으로 인해 지표지질조사가 불가능하여 단충대를 파악하기가 쉽지 않다. 하상 전기비저항 탐사는 하저지반에 대한 연속적인 영상을 제공하여 주므로 단층이나 연약대의 위치를 파악하는데 매우 효과적인 탐사법이다. 하저터널의 설계에서는 단층대의 위치뿐만 아니라 단층대의 주향방향이 매우 중요한 요소이다. 단충대의 주향방향을 파악하는 방법으로는 격자형의 촉선에 대한 광대역 조사가 매우 효과적이다. 하지만, 종래의 하상 전기비저항 탐사는 케이블을 하저에 설치하여야 하므로 광대역 조사에 적합하지 않다. 이에 이 연구에서는 소형보트에 스트리머 케이블을 설치하여 신속하게 광대역의 하저지반을 영상화하는 스트리머 전기비저항 탐사의 적용성에 대해 고찰하였다.

스트리머 전기비저항 탐사에 의한 단층대의 분해능을 고찰하기 위하여, 수직단층이 수층 하부의 퇴적충에 피복되어 있는 모형을 설정하여 수치모형실험을 수행하였다. 전극의 설치위치와 수심의 변화에 따른 수직단층의 분해능에 대해 살펴보았으며, 그 결과 수층의 두께가 전극간격의 2 배 이내인 경우에는 전극을 수층 표면에 설치하는 방식으로도 단층을 영상화할 수 있음을 보였다. 또한, 스트리머 전기비저항 탐사에 적합한 4 가지의 전극배열법을 선정하여 신호대 잡음비와 수직 단층의 분해능을 비교 검토하였다. 수치모형실험을 기초로 하여 한국 서울에 위치한 한강의 하저터널 예정부지에서 하상 전기비저항 탐사를 수행하였다. 하저터널 예정노선에서는 고분해능의 영상이 요구되므로 하저에 전극을 설치하여 자료를 획득하였으며, 2 차원 역산을 적용하여 강 양단에서 단층대로 추정되는 3 개의 저비저항 이상대롤 탐지하였다. 저비저항 이상대의 원인을 규명하기 위하여 시추조사를 수행하였으며, 그 결과 수 $\mathrm{m}$ 이상의 폭을 가지는 다수의 단층이 관측되었다. 단층대의 주향방향을 탐지하기 위하여 확인된 저비저항 이상대를 중심으로 격자형의 측선을 설정하여 스트리머 전기비저항 탐사를 수행하였다. 이를 통해 하저에 케이블을 설치하는 방식에 비해 매우 신속하고 경제적으로 하저에 분포하는 이상대의 분포범위와 발달방향을 규명할 수 있었다.

\footnotetext{
1 産業技術総合研究所 地囷資源環㑽研究部門 厂 $305-8567$ つぐ仿束 $1-1$-1 中央第 7 2 韓国地質資源研究院 地盤安全研究部

3 (株)ヒーツンンジオテク

4 (株)エスココンサルタント

5 三星物産(株) 建設部阴
}

\section{1 산업기술종합연구소 지권자원환경연구부문}

2 한국지질자원연구원 지반안전연구부

3 (주)희송지오텍

4 (주)에스코컨설턴트

5 삽성물산(주) 건설부문 